\title{
Interaction of Yersinia enterocolitica and $Y$. pseudotuberculosis with platelets
}

\author{
MICHAEL SHEPEL*, JESSICA BOYD*, JOANNE LUIDER* and ALAN P. GIBB* + * \\ * Department of Microbiology \& Infectious Diseases, †Department of Pathology \& Laboratory Medicine, \\ University of Calgary and \$Calgary Laboratory Services, Calgary, Canada
}

\begin{abstract}
Yersinia enterocolitica is a bacterium capable of growth at $4^{\circ} \mathrm{C}$ in donated blood and has been responsible for many deaths following transfusion. Interaction of $Y$. enterocolitica with blood cells is of interest in understanding the mechanisms of survival and growth in blood. The closely related organism $Y$. pseudotuberculosis is known to invade platelets and cause platelet aggregation by a mechanism that involves expression of the chromosomal inv gene. Yersinia isolates were made to express green fluorescent protein (GFP) and their interaction with platelets was studied by flow cytometry. $Y$. enterocolitica did not cause platelet aggregation or activation, not even when grown at $22^{\circ} \mathrm{C}$ to maximise inv expression. Attachment of $Y$. enterocolitica $0: 9$ to platelets occurred with virulence plasmid-bearing $\left(\mathrm{pYV}^{+}\right)$strains grown at $37^{\circ} \mathrm{C}$ but not with pYV ${ }^{-}$strains nor with strains grown at $22^{\circ} \mathrm{C}$. Y. pseudotuberculosis containing inv did cause platelet activation and aggregation when grown at $22^{\circ} \mathrm{C}$, as has been shown before, but also showed enhanced attachment to platelets when grown at $37^{\circ} \mathrm{C}$. Electron microscopy studies confirmed that inv-expressing $Y$. pseudotuberculosis invaded platelets but $Y$. enterocolitica attached only to the outer surface of platelets. Interaction of $Y$. enterocolitica 0:9 with platelets provided a modest protection against bacterial killing by human serum. Interaction of $Y$. enterocolitica $0: 9$ with platelets does not lead to platelet invasion or activation, and is mediated through plasmid-coded factors, not inv.
\end{abstract}

\section{Introduction}

The enteric pathogen Yersinia enterocolitica has been the leading cause of bacterial growth in stored donated blood for the past 15 years [1-3]. At least 21 cases of $Y$. enterocolitica transfusion-related sepsis, of which 12 resulted in death, have occurred in the USA since 1982 [4] and a similar or greater number of cases has been reported from other developed countries [3]. Growth of $Y$. enterocolitica in donated blood is associated with mild gastrointestinal illness and serological evidence of acute infection in the donor. Therefore, Y. enterocolitica contamination is thought to be the result of asymptomatic bacteraemia in the donor. Y. enterocolitica serotypes involved have included O:3, O:9, $\mathrm{O}: 1,2,3 ; 0: 5,27$ and $\mathrm{O}: 20$, but not $\mathrm{O}: 8$ [5].

The ability of $Y$. enterocolitica to grow at $4^{\circ} \mathrm{C}$ is presumed to be a critical factor in its ability to multiply

Received 31 May 2001; accepted 5 June 2001.

Corresponding author: Dr A. P. Gibb (e-mail: a.p.gibb@ed. ac.uk). Present address: Department of Medical Microbiology, Medical School, Teviot Place, Edinburgh EH8 9AG, UK. in donated blood. In addition, Y. enterocolitica has several temperature-regulated virulence factors that may be relevant. YadA is an adhesin encoded by the $Y$. enterocolitica virulence plasmid pYV [6]. YadA is expressed at $37^{\circ} \mathrm{C}$ and plays a role in adhesion to leucocytes and prevention of phagocytosis and killing by those cells [7]. Complement resistance involves both the virulence plasmid (pYV) $[8,9]$ and chromosomal factors [10], and is also best expressed at $37^{\circ} \mathrm{C}$. Invasin, encoded by the chromosomal inv gene, is best expressed in vitro at temperatures below $30^{\circ} \mathrm{C}$ [11]. Invasin expression by $Y$. enterocolitica leads to invasion of epithelial cells and invasin in the closely related $Y$. pseudotuberculosis has been shown to cause invasion and aggregation of platelets [12]. The potential role of invasin of $Y$. enterocolitica in promoting interactions with blood cells in whole blood is unclear [13].

The interaction of $Y$. enterocolitica with donated blood is likely to be complex. The bacteria must cope with complement and immune cells in the host and with the drop in temperature to $4^{\circ} \mathrm{C}$ over c. $8 \mathrm{~h}$ [14] after the blood is collected. $Y$. enterocolitica is expected to be extracellular in the infected donor, as in the tissues of 
animal models [15-17], so that expression of complement resistance would be essential for survival of the organism in the donor blood before donation. Expression of yadA is likely to be important in the donor blood before donation in preventing phagocytosis [7]. Complement resistance is likely to be lost in a few hours after blood donation as the blood cools [18]. Cooling will cause down-regulation of yadA expression, and up-regulation of inv expression. The activity of complement and phagocytes will also diminish as the temperature drops.

Experimental studies of inoculation of $Y$. enterocolitica into fresh donated blood have been conducted to try to understand the mechanisms involved in bacterial survival and growth. These experiments have consistently shown that most of the organisms inoculated are killed rapidly by the action of complement [18, 19]. The few inoculated bacteria that survive may be protected from complement by being inside a cell. These bacteria then multiply to high numbers after $c .2$ weeks. It has been suggested that bacteria survive inside leucocytes [20], but this has not been demonstrated directly, and platelets might also provide some protection.

The present study aimed to explore the possibility that platelets might be a site of survival of $Y$. enterocolitica in donated blood. Y. pseudotuberculosis has been found to be associated with platelets in experimental infection [16]. Y. enterocolitica has also been observed to be associated with platelets in the peripheral blood of a patient with overwhelming $Y$. enterocolitica sepsis (A. P. Gibb, unpublished observation). Y. pseudotuberculosis can invade platelets through a mechanism that requires invasin expression [12]. As invasin expression and function are very similar in $Y$. enterocolitica and $Y$. pseudotuberculosis [21] it seemed likely that $Y$. enterocolitica might also invade platelets. This might occur as donated blood cooled and invasin expression increased. In these circumstances $Y$. enterocolitica might be protected from complement by the platelets. Therefore, the present study aimed to investigate the interaction of yersiniae with platelets, with green fluorescent protein (GFP)-expressing bacteria and flow cytometry as the primary tools.

\section{Materials and methods}

\section{Bacterial strains and plasmids}

All bacteria and plasmids used in this work are listed in Table 1 [12, 18, 22-27]. Plasmids were prepared and constructed by the alkaline lysis method [28] and standard recombinant DNA techniques [29]. Enzymes were purchased either from Bethesda Research Laboratories (Gaithersburg, MD, USA), or from New England Biolabs (Beverly, MA, USA). Bacteria were

Table 1. Bacterial strains and plasmids

\begin{tabular}{|c|c|c|}
\hline Designation & Description or genotype & Reference or source \\
\hline \multicolumn{3}{|l|}{ Bacteria } \\
\hline 3169 & Y. enterocolitica serotype $\mathrm{O}: 9, \mathrm{pYV}^{+}$, from a case of transfusion-associated sepsis & 18 \\
\hline WA-314 & Y. enterocolitica serotype $\mathrm{O}: 8$, with virulence plasmid $(\mathrm{pYVO} 8)^{+}$ & 23 \\
\hline YPIII & Y. pseudotuberculosis $\mathrm{pYV}^{+}$ & 12 \\
\hline YPIIIc & Y. pseudotuberculosis $\mathrm{pYV}^{-}$ & 12 \\
\hline 32815 & Human enteric isolate of $Y$. enterocolitica serotype $0: 7,8$, biotype $1 \mathrm{~A}$ & $*$ \\
\hline 21553 & Human enteric isolate of $Y$. enterocolitica serotype $0: 7,8$, biotype $1 \mathrm{~A}$ & $*$ \\
\hline 56167 & Human enteric isolate of $Y$. enterocolitica serotype O:7,8, biotype 1A & $*$ \\
\hline 9347 & Human enteric isolate of $Y$. enterocolitica serotype not typable biotype IA & $*$ \\
\hline 7515 & Human enteric isolate of $Y$. enterocolitica serotype $0: 9$, biotype $1 \mathrm{~B}$ & $*$ \\
\hline 11475 & Human enteric isolate of $Y$. enterocolitica serotype $0: 9$, biotype $1 \mathrm{~B}$ & $*$ \\
\hline 3327 & Y. enterocolitica from transfusion-associated sepsis, serotype $0: 5,27$ & 25 \\
\hline ER1325 & Y. enterocolitica, serotype $\mathrm{O}: 8, \mathrm{pYV}^{+}$ & $\dagger$ \\
\hline ER2601 & Y. enterocolitica, serotype $\mathrm{O}: 8, \mathrm{pYV}^{+}$ & $\dagger$ \\
\hline JM109 & $\begin{array}{l}\text { Escherichia coli endA1, gyrA96, hsdR } 17\left(\mathrm{rk}^{-} \mathrm{mk}^{+}\right), \mathrm{mcrB}^{+}, \text {recA1, relA1, supE44, } \\
\text { thi-1, } \Delta \text { (lac-proAB), } \mathrm{F}^{\prime}[\operatorname{traD} 36, \text { proAB, lacIqZ } \Delta \mathrm{M} 15]\end{array}$ & 26 \\
\hline \multicolumn{3}{|c|}{ 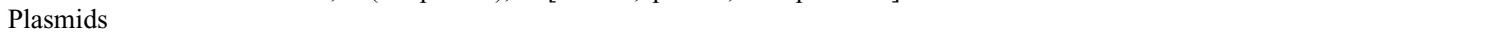 } \\
\hline GFP plasmids & pGFPM1, pGFPM2, pGFPM3 & 22 \\
\hline pUCP22 & Broad host-range vector, lac promoter Gent ${ }^{R}, A p^{R}$ & 27 \\
\hline pYG1 & pUCP22 with gfpM1 & This study \\
\hline pYG2 & pUCP22 with gfpM2 & This study \\
\hline pYG3 & pUCP22 with gfpM3 & This study \\
\hline pACYC 184-GFP & Broad host-range plasmid expressing GFP & * \\
\hline
\end{tabular}

*Human isolates of $Y$. enterocolitica provided by the Provincial Laboratory for Public Health of Southern Alberta.

${ }^{\dagger}$ Human isolates of $Y$. enterocolitica O:8 were provided by Dr Neal Denhollander, Yersinia Reference Laboratory, Toronto. tpACYC 184-GFP was a gift from Dr J. Mescas, Stanford University School of Medicine. 
grown in low salt Luria Broth (LLB, Gibco BRL, Gaithersburg, MD, USA). Antibiotics were used at the following concentrations: Escherichia coli - ampicillin $100 \mathrm{mg} / \mathrm{L}$, kanamycin $25 \mathrm{mg} / \mathrm{L}$; for $Y$. enterocolitica gentamicin $60 \mathrm{mg} / \mathrm{L}$, kanamycin $25 \mathrm{mg} / \mathrm{L}$. Congo redmagnesium oxalate agar medium [30] was used to confirm the presence of $\mathrm{pYV}^{+}$in $Y$. enterocolitica and $Y$. pseudotuberculosis strains before each experiment.

\section{GFP constructs}

Three red-shifted $g f p$ clones used in this study, M1, M2 and M3, were a gift from Brendan Cormack [22]. All three genes were cloned into the broad host range vector pUCP22 and expressed from the constitutive lac promoter. These three constructs, pYG1, pYG2, pYG3, and the vector control were moved into $Y$. enterocolitica by electroporation [31].

\section{Bacterial preparation}

After an initial incubation for $18 \mathrm{~h}$ at either $22^{\circ} \mathrm{C}$ or $37^{\circ} \mathrm{C}$, bacteria were washed once and resuspended in calcium- and magnesium-free phosphate-buffered saline (PBS; Gibco BRL). Bacteria were counted with Flow-Count ${ }^{\mathrm{TM}}$ Fluorospheres (Beckman-Coulter, FL, USA) and adjusted to $1 \times 10^{11}$ bacteria/L. To maximise expression of genes on the virulence plasmid, strains were cultured overnight at $22^{\circ} \mathrm{C}$ with appropriate antibiotics, diluted 1 in 50 in LLB containing $20 \mathrm{~mm}$ sodium oxalate and $20 \mathrm{~mm}$ magnesium chloride solution, incubated for $2 \mathrm{~h}$ at $37^{\circ} \mathrm{C}$, washed and resuspended in PBS [18].

\section{Preparation of human platelets}

Citrated whole blood was collected from one of five subjects. All were tested and found to be negative for antibodies to $Y$. enterocolitica and $Y$. pseudotuberculosis (tests performed by $\mathrm{Dr}$ Neal Denhollander, Yersinia Reference Laboratory, Toronto, Canada). Platelet-rich plasma (PRP) was obtained from citrated whole blood by centrifugation at $300 \mathrm{~g}$ for $10 \mathrm{~min}$ $\left(4^{\circ} \mathrm{C}\right)$. The PRP was washed and resuspended in calcium- and magnesium-free PBS, and platelets were counted with Flow-Count ${ }^{\mathrm{TM}}$ Fluorospheres and adjusted to $1 \times 10^{8}$ platelets/L. Platelet preparations were used within $2 \mathrm{~h}$ of collection.

\section{Preparation of human serum}

Whole blood samples from the five subjects described above were collected and allowed to coagulate for $15 \mathrm{~min}$ at $22^{\circ} \mathrm{C}$. Serum was obtained by centrifugation of the coagulated blood at $500 \mathrm{~g}$ for $10 \mathrm{~min}\left(4^{\circ} \mathrm{C}\right)$ and was immediately frozen and stored at $-70^{\circ} \mathrm{C}$.

\section{Flow cytometry}

Unlabelled bacteria, GFP-labelled bacteria, unlabelled platelets and platelets stained with CD42b-PC5 antibody (Beckman-Coulter) were analysed with a Coulter XL-MCL (Beckman-Coulter) flow cytometer to determine appropriate voltages and compensation settings for size (log forward scatter), granularity (log side scatter), green fluorescence and red fluorescence.

\section{Platelet adhesion assay}

Bacteria were grown overnight at either $22^{\circ} \mathrm{C}$ or $37^{\circ} \mathrm{C}$ in LLB with appropriate antibiotics, washed and resuspended in PBS. Then $1 \times 10^{6}$ platelets and $5 \times 10^{6}$ bacteria were combined in PBS to a total volume of $100 \mu \mathrm{l}$. Tests were incubated at either $22^{\circ} \mathrm{C}$ or $37^{\circ} \mathrm{C}$ for $1 \mathrm{~h}$. After incubation, platelets were stained with CD42b-PC5 for $10 \mathrm{~min}$ at $22^{\circ} \mathrm{C}$ and then diluted to a total volume of $1 \mathrm{ml}$ with $\mathrm{PBS}$ for immediate analysis by flow cytometry. A minimum of 5000 platelet events was analysed per sample. Two parameter fluorescent histograms (CD42b-PC5 versus GFP) were generated for analysis, gated on either GFP-positive or CD42b-positive events. The percentage of platelets co-staining with GFP and the percentage of bacteria co-staining with CD42b were recorded.

\section{Platelet aggregation assay}

Platelet preparation and aggregation assay followed standard methods [32] with $230 \mu 1$ of PRP incubated with a $60-\mu \mathrm{l}$ suspension containing $2 \times 10^{7}$ bacteria (resulting in a platelet to bacteria ratio of $1: 3$ ) in a John's Scientific Platelet Aggregation Profiler, Model PAP-4 (BIO/DATA Corporation, Hatboro, PA, USA).

\section{Platelet activation assay by flow cytometry}

Bacterial strains were grown overnight at $22^{\circ} \mathrm{C}$ or $37^{\circ} \mathrm{C}$, then $5 \times 10^{6}$ bacteria and $1 \times 10^{6}$ platelets were incubated in $100 \mu \mathrm{l}$ of PBS for $1 \mathrm{~h}$ at either $22^{\circ} \mathrm{C}$ or $37^{\circ} \mathrm{C}$. Platelets were stained for $15 \mathrm{~min}$ at $22^{\circ} \mathrm{C}$ with CD42b-PC5 and either CD62P-PE, a marker for platelet activation [33], or mouse immunoglobulin-PE (Beckman-Coulter), an isotype control antibody. At least 5000 platelet events were analysed per sample. Two parameter fluorescent histograms gated on CD42bpositive events were generated for analysis (CD42bPC5 versus mouse immunoglobulin and CD42b-PC5 versus CD62P-PE). Platelet activation was determined by subtracting the percentage of platelets staining with mouse immunoglobulin from the percentage of platelets staining with CD62P.

\section{Platelet protection assay by culture}

Platelet and bacterial preparations were performed as described in the flow cytometry experiments. Tests were performed in triplicate; $10 \times 10^{6}$ bacteria and $2 \times 10^{6}$ platelets were used in each test. A control was made with $10 \times 10^{6}$ bacteria without platelets. Bacteria with or without platelets were incubated for $1 \mathrm{~h}$ at 
$37^{\circ} \mathrm{C}$. Half of the sample was removed, treated with Triton X-100 $1 \%$ for $15 \mathrm{~min}$ at $22^{\circ} \mathrm{C}$, serially diluted and triplicate $100-\mu 1$ samples were spread on LLB agar and incubated for $36 \mathrm{~h}$ at $28^{\circ} \mathrm{C}$. Serum was added to the remaining sample to a concentration of $30 \%$ and incubated at $37^{\circ} \mathrm{C}$ for $2 \mathrm{~h}$. The samples were then treated with Triton X-100 $1 \%$ for $15 \mathrm{~min}$ at $22^{\circ} \mathrm{C}$ and plate counts were performed as above. Survival in serum was determined by comparing the number of colonies that survived the serum treatment with the number of colonies in the same samples before serum treatment. A platelet protection ratio was calculated as (survival of bacteria pre-incubated with platelets)/ (survival of bacteria without platelets).

\section{Platelet protection assay by flow cytometry}

Tests were performed in triplicate with platelets and serum from three subjects. Each test consisted of $30 \times 10^{6}$ washed platelets and $3 \times 10^{6}$ washed bacteria with PBS added to a total volume of $300 \mu \mathrm{l}$. Washed bacteria without platelets were used as a control. After incubation at $37^{\circ} \mathrm{C}$ for $1 \mathrm{~h}, 100 \mu \mathrm{l}$ were removed and stained for $10 \mathrm{~min}$ at $22^{\circ} \mathrm{C}$ with $\mathrm{CD} 42 \mathrm{~b}$, diluted with $1 \mathrm{ml}$ of $\mathrm{PBS}$ and $100 \mu \mathrm{l}$ of Flow-Count ${ }^{\mathrm{TM}}$ Fluorospheres and analysed on the flow cytometer as described in the platelet adhesion assay. The percentage of bacteria co-staining with CD42b and the total number of GFP events were recorded. The remaining $200 \mu \mathrm{l}$ were added to $300 \mu \mathrm{l}$ of thawed fresh-frozen serum from the platelet donor and $500 \mu \mathrm{l}$ of PBS with $\mathrm{Mg}^{2+}$ and $\mathrm{Ca}^{2+}$ for a total volume of $1 \mathrm{ml}$ containing serum $30 \%$. After incubation for $2 \mathrm{~h}$ at $37^{\circ} \mathrm{C}, 500 \mu \mathrm{l}$ were diluted in PBS with Triton X-100 1\% to a volume of $2 \mathrm{ml}$ and incubated for $15 \mathrm{~min}$ at $22^{\circ} \mathrm{C}$. FlowCount $^{\mathrm{TM}}$ Fluorospheres were added and the number of GFP events was counted on the flow cytometer. Bacterial survival was defined as the number of GFP events found divided by the number in a serum-free control.

\section{Electron microscopy}

Human cells and bacteria were centrifuged at $800 \mathrm{~g}$ and the supernate was removed. The pellet was fixed for $2 \mathrm{~h}$ at $20^{\circ} \mathrm{C}$ in Karnovsky's fixative with the addition of ruthenium hexamine trichloride (Polysciences) $0.7 \%$. After fixation, the pellet was rinsed in cacodylate buffer $0.1 \%$ containing $5 \mathrm{mM}$ calcium $(\mathrm{pH} 7.4)$. The pellet was centrifuged and post-fixed in osmium tetroxide $1 \%$ for $1 \mathrm{~h}$ at $20^{\circ} \mathrm{C}$. The fixative was removed and the pellet was dehydrated in graded alcohols, infiltrated and embedded in Spurrs resin. Thin sections $(80-100 \mathrm{~nm})$ were cut with a diamond knife on a Reichert OM-U3 ultra-microtome, mounted on grids, stained with uranyl acetate and lead nitrate, and examined with a Hitachi H-7000 electron microscope operated at $75 \mathrm{kV}$.

\section{Results}

pYG plasmid as an effective bacterial label for flow cytometry

Y. enterocolitica strains UC310, 3169 and 3169L carrying pUCP22, pYG1, pYG2 or pYG3 were analysed with a flow cytometer. pYG3 was determined to have the brightest fluorescence and was chosen for subsequent experiments. Evaluation by flow cytometry demonstrated that GFP-labelled bacteria could be resolved from CD42b-PC5-stained platelets (Fig. 1) and Flow-Count ${ }^{\mathrm{TM}}$ Fluorospheres by fluorescence and size parameters. Furthermore, it was shown that the GFP signal was stable in the presence of heat-treated serum but was lost in fresh serum at a concentration similar to that which caused bacterial killing and could, therefore, be used as a measure of complement action (Fig. 2). The loss of GFP signal was interpreted as leakage of GFP protein following membrane disruption.

\section{Effect of temperature and virulence plasmid $(p Y V)$ on the interaction of $Y$. enterocolitica with purified human platelets}

When $\mathrm{pYG}^{+}, \mathrm{pYV}^{+}$Y. enterocolitica strain 3169 was grown at $37^{\circ} \mathrm{C}$ and incubated with platelets at $37^{\circ} \mathrm{C}$, 93\% of platelets were associated with GFP signal (Fig. 3 ). In contrast, when $\mathrm{pYG}^{+}$strain 3169 was grown and incubated at $22^{\circ} \mathrm{C}$, only $11.5 \%$ of platelets were associated with bacteria. The $\mathrm{pYV}^{-} Y$. enterocolitica strain $3169 \mathrm{~L}$ associated with $<10 \%$ of platelets at either $22^{\circ} \mathrm{C}$ or $37^{\circ} \mathrm{C}$ and similar low results were seen with the $E$. coli control strain. This clearly shows that

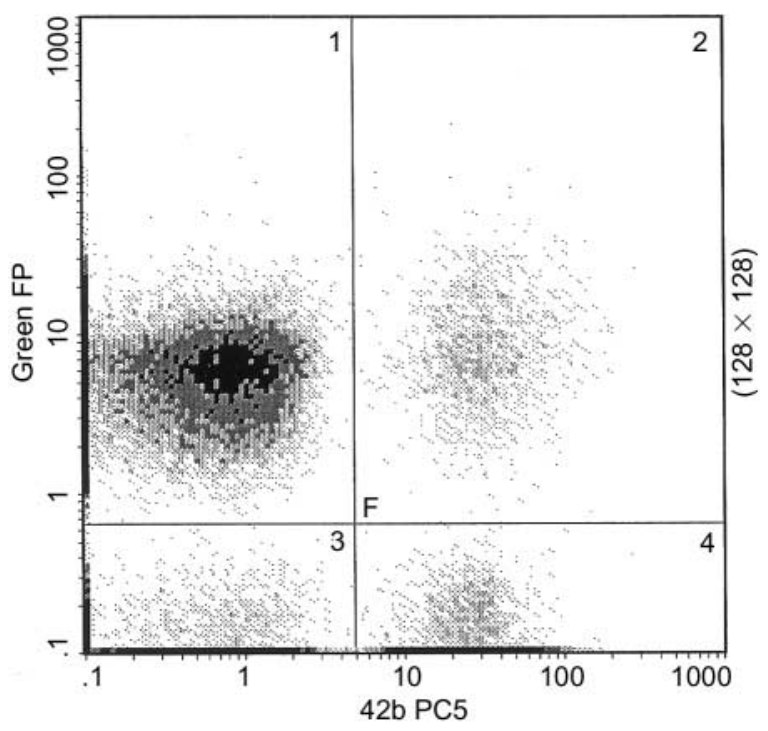

Fig. 1. Flow cytometric analysis of the interaction of $Y$. enterocolitica with platelets. Ungated histogram showing interaction of Y. enterocolitica 3169 (pYG3) with platelets at $37^{\circ} \mathrm{C}$. Region 1 contains fluorescent bacteria (GFP events). Region 2 contains CD42b-PC5-labelled platelets co-staining with GFP. Region 3 contains RBC debris and non-fluorescent bacteria. Region 4 contains CD42b-PC5-labelled platelets. 


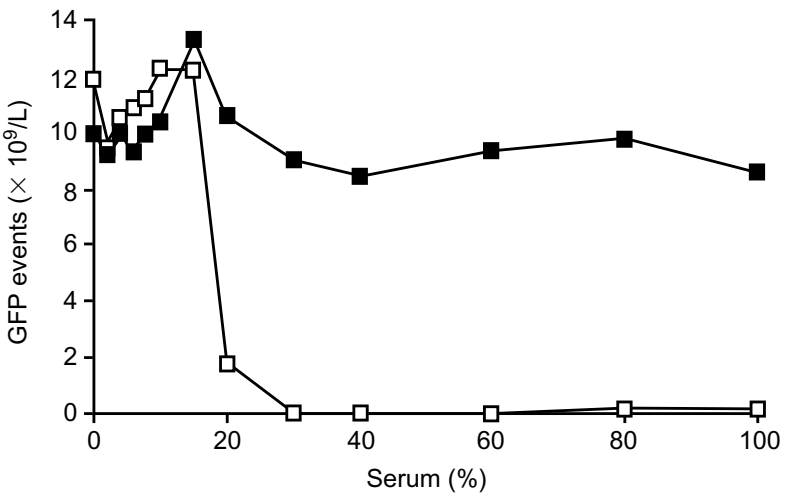

Fig. 2. Complement activity assay by flow cytometry. Y. enterocolitica $3169 \mathrm{~L}$ expressing GFP was grown overnight at $37^{\circ} \mathrm{C}$; $1 \times 10^{6}$ bacteria were added to serial dilutions of normal $(\square)$ or heat-treated $(\square)$ serum and incubated for $2 \mathrm{~h}$ at $37^{\circ} \mathrm{C}$. Heattreated serum was incubated at $56^{\circ} \mathrm{C}$ for $30 \mathrm{~min}$. After incubation, $100 \mu \mathrm{l}$ of Flow-Count ${ }^{\mathrm{TM}}$ Fluorospheres were added and the number of GFP events was counted.

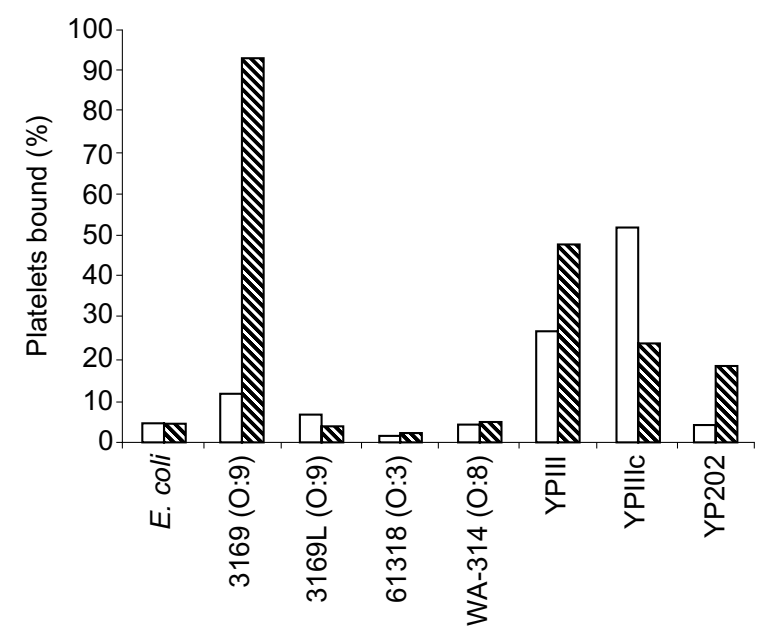

Fig. 3. Association of GFP-expressing bacteria with platelets. Strains were grown and incubated at $22^{\circ} \mathrm{C}(\square)$ and $37^{\circ} \mathrm{C}(\mathbb{N})$ to assess the role of plasmid or chromosomally encoded genes in platelet association. E. coli strain JM109 was used as a negative control for platelet association. Association was determined by dual staining of platelets with CD42b-PC5 and GFP. Results are an average of five replicates conducted on three different blood donors. Platelets were incubated with bacteria for $60 \mathrm{~min}$ at a bacteria to platelet ratio of 5:1. Representative results for $Y$. enterocolitica serotypes O:3, O:8 and O:9 are shown, together with Y. pseudotuberculosis (YP) strains.

one or more genes carried by the plasmid and induced at $37^{\circ} \mathrm{C}$ is responsible for the platelet association.

Further platelet association tests were performed with other $\mathrm{pYV}^{+} Y$. enterocolitica strains of serotypes $\mathrm{O}: 3$, $\mathrm{O}: 8$ and O:9. Both of two additional O:9 strains tested associated with platelets at $37^{\circ} \mathrm{C}$ but not at $22^{\circ} \mathrm{C}$. The $\mathrm{O}: 8$ strain and the $\mathrm{O}: 3$ strains did not associate with platelets at either temperature (Fig. 3 and Table 2).

The observation of a pYV-dependent interaction between $Y$. enterocolitica $\mathrm{O}: 9$ and platelets in flow cytometry was very different from the interaction of $Y$. pseudotuberculosis with platelets in the aggregometer system in which invasin expression plays a key role [12]. Therefore, the interaction of platelets with $Y$. pseudotuberculosis in the flow system and the interaction of platelets with $Y$. enterocolitica in the aggregometer were investigated to determine whether the differences observed were related to methodology or bacterial factors.

\section{Interaction between Y. pseudotuberculosis and platelets in the flow system}

$Y$. pseudotuberculosis strains were made to express GFP by insertion of the pACYC 184-GFP, and their interaction with platelets was analysed by flow cytometry (Fig. 3). A more complex picture was observed than had been seen with $Y$. enterocolitica. The $\mathrm{pYV}^{-}$strains YPIIIc and YP202 both associated with c. $20 \%$ of platelets at $37^{\circ} \mathrm{C}$. Association was reduced to background levels at $22^{\circ} \mathrm{C}$ in the $i n v^{-}$strain YP202, but increased to c. $50 \%$ in the isogenic $i n v^{+}$ strain. The $\mathrm{pYV}^{+}$strain YPIII showed greater platelet association than strain YPIIIc at $37^{\circ} \mathrm{C}$ but less association at $22^{\circ} \mathrm{C}$. These results suggest a role for a chromosomal adhesin expressed at $37^{\circ} \mathrm{C}$ such as psa [34], as well as invasin and a plasmid factor expressed at $37^{\circ} \mathrm{C}$.

\section{Platelet aggregation by Y. pseudotuberculosis and Y. enterocolitica}

The present study was able to replicate the key observations obtained by Simonet et al. [12] in the aggregometer system. Platelet aggregation by $Y$. pseudotuberculosis occurred only when the organisms were grown at low temperature, was independent of the presence of the virulence plasmid and did not occur with the $i n v^{-}$strain (Table 2). Platelet aggregation by $Y$. enterocolitica strains 3169 and 3169L was then examined under identical conditions. No platelet aggregation was observed at any of the growth temperatures. As it was possible that strain 3169 was defective in some aspect of invasin expression or function, 12 other unrelated $Y$. enterocolitica strains of various serotypes $(\mathrm{O}: 3, \mathrm{O}: 9, \mathrm{O}: 7,8$ and $\mathrm{O}: 8)$ were tested and none of them produced platelet aggregation in the aggregometer system.

\section{Platelet activation by Yersinia}

The findings that $Y$. enterocolitica $0: 9$ associated with platelets in the flow system but did not cause aggregation and that $Y$. pseudotuberculosis YPIII adhered to platelets at $37^{\circ} \mathrm{C}$ but did not cause aggregation at that temperature suggest that adherence can occur without platelet activation. Platelet activation was examined by flow cytometry with an antibody to the platelet protein CD62P, a marker of platelet activation [33]. When grown at $22^{\circ} \mathrm{C}$, strains YPIII and YPIIIc 
Table 2. Summary of interactions of Yersinia with platelets

\begin{tabular}{|c|c|c|c|c|c|}
\hline $\begin{array}{l}\text { Strain } \\
\text { no. }\end{array}$ & Serotype & Temperature & $\begin{array}{c}\text { Platelet } \\
\text { association }\end{array}$ & $\begin{array}{l}\text { Platelet } \\
\text { aggregation }\end{array}$ & $\begin{array}{c}\text { CD62P } \\
\text { expression }\end{array}$ \\
\hline \multirow[t]{2}{*}{3169} & O:9 & $37^{\circ} \mathrm{C}$ & +++ & - & - \\
\hline & & $22^{\circ} \mathrm{C}$ & - & - & - \\
\hline \multirow[t]{2}{*}{$3169 \mathrm{~L}$} & O:9 & $37^{\circ} \mathrm{C}$ & - & - & - \\
\hline & & $22^{\circ} \mathrm{C}$ & - & - & - \\
\hline \multirow[t]{2}{*}{7515} & O:9 & $37^{\circ}$ & +++ & - & ND \\
\hline & & $22^{\circ} \mathrm{C}$ & - & - & ND \\
\hline \multirow[t]{2}{*}{11475} & O:9 & $37^{\circ} \mathrm{C}$ & +++ & - & ND \\
\hline & & $22^{\circ} \mathrm{C}$ & - & - & ND \\
\hline \multirow[t]{2}{*}{ YPIII } & & $37^{\circ} \mathrm{C}$ & ++ & - & - \\
\hline & & $22^{\circ} \mathrm{C}$ & + & +++ & +++ \\
\hline \multirow[t]{2}{*}{ YPIIIc } & & $37^{\circ} \mathrm{C}$ & + & - & - \\
\hline & & $22^{\circ} \mathrm{C}$ & ++ & +++ & +++ \\
\hline \multirow[t]{2}{*}{ YP202 } & & $37^{\circ} \mathrm{C}$ & + & - & - \\
\hline & & $22^{\circ} \mathrm{C}$ & - & - & - \\
\hline \multirow{2}{*}{ WA-314 } & O:8 & $37^{\circ} \mathrm{C}$ & - & ND & ND \\
\hline & & $22^{\circ} \mathrm{C}$ & - & ND & ND \\
\hline \multirow[t]{2}{*}{ ER1325 } & O:8 & $37^{\circ} \mathrm{C}$ & - & ND & ND \\
\hline & & $22^{\circ} \mathrm{C}$ & - & ND & ND \\
\hline \multirow[t]{2}{*}{ ER2601 } & $0: 8$ & $37^{\circ} \mathrm{C}$ & - & ND & ND \\
\hline & & $22^{\circ} \mathrm{C}$ & - & ND & ND \\
\hline \multirow[t]{2}{*}{61318} & O:3 & $37^{\circ} \mathrm{C}$ & - & - & ND \\
\hline & & $22^{\circ} \mathrm{C}$ & - & - & ND \\
\hline \multirow[t]{2}{*}{64225} & O:3 & $37^{\circ} \mathrm{C}$ & - & - & ND \\
\hline & & $22^{\circ} \mathrm{C}$ & - & - & ND \\
\hline \multirow[t]{2}{*}{66364} & O:3 & $37^{\circ} \mathrm{C}$ & - & - & ND \\
\hline & & $22^{\circ} \mathrm{C}$ & - & - & ND \\
\hline \multirow[t]{2}{*}{116731} & O:3 & $37^{\circ} \mathrm{C}$ & - & - & ND \\
\hline & & $22^{\circ} \mathrm{C}$ & - & - & ND \\
\hline \multirow[t]{2}{*}{3327} & O:5,27 & $37^{\circ} \mathrm{C}$ & ND & - & ND \\
\hline & & $22^{\circ} \mathrm{C}$ & ND & - & ND \\
\hline \multirow[t]{2}{*}{32815} & $\mathrm{O}: 7,8$ & $37^{\circ} \mathrm{C}$ & ND & - & ND \\
\hline & & $22^{\circ} \mathrm{C}$ & ND & - & ND \\
\hline \multirow[t]{2}{*}{21553} & $\mathrm{O}: 7,8$ & $37^{\circ} \mathrm{C}$ & ND & - & ND \\
\hline & & $22^{\circ} \mathrm{C}$ & ND & - & ND \\
\hline \multirow[t]{2}{*}{56167} & $\mathrm{O}: 7,8$ & $37^{\circ} \mathrm{C}$ & ND & - & ND \\
\hline & & $22^{\circ} \mathrm{C}$ & ND & - & ND \\
\hline \multirow[t]{2}{*}{9347} & NT & $37^{\circ} \mathrm{C}$ & ND & - & ND \\
\hline & & $22^{\circ} \mathrm{C}$ & ND & - & ND \\
\hline
\end{tabular}

ND, not done.

were able to activate platelets readily. In contrast, strain YP202 and Y. enterocolitica strains 3169 and 3169L did not activate platelets (Fig. 4). No platelet activation was observed if bacteria were grown overnight at $37^{\circ} \mathrm{C}$ despite association of the bacteria with platelets (Table 2 and Fig. 4).

Physical interaction of $Y$. pseudotuberculosis and $Y$. enterocolitica with platelets

EM studies with ruthenium red staining to distinguish vesicles from invaginations confirmed that invasinexpressing Y. pseudotuberculosis invaded platelets and was found inside vesicles which were not accessible to ruthenium red staining [12] (Fig. 5a). Y. enterocolitica did not invade platelets in this way, but was seen tightly associated with them, often appearing completely 'wrapped up' by a number of platelets (Fig. 5b).

\section{Platelets and complement survival}

The tight association of $Y$. enterocolitica O:9 with platelets might offer protection against complement, increasing the survival of $Y$. enterocolitica in blood products. This possibility was examined in conventional culture and by flow cytometry. In conventional culture assay in individual experiments with wild-type $\mathrm{pYG}^{-}$strain 3169 , platelet protection ratios of 3.2 , 14.5 and 27.5, respectively, were obtained in platelets from three different donors. In the flow cytometry assay, association with platelets increased the survival of $Y$. enterocolitica (as determined by preservation of GFP signal) by approximately two-fold (Fig. 6).

\section{Discussion}

Flow cytometry with GFP-expressing bacteria is a useful way of investigating the interaction of bacteria with cells. The method is particularly useful for platelets because their small size and instability would make analysis in other systems very difficult. The method has the advantage that large numbers of observations can be made quickly and the results can be captured in electronic form with minimal manipulations.

Y. enterocolitica and Y. pseudotuberculosis interact 

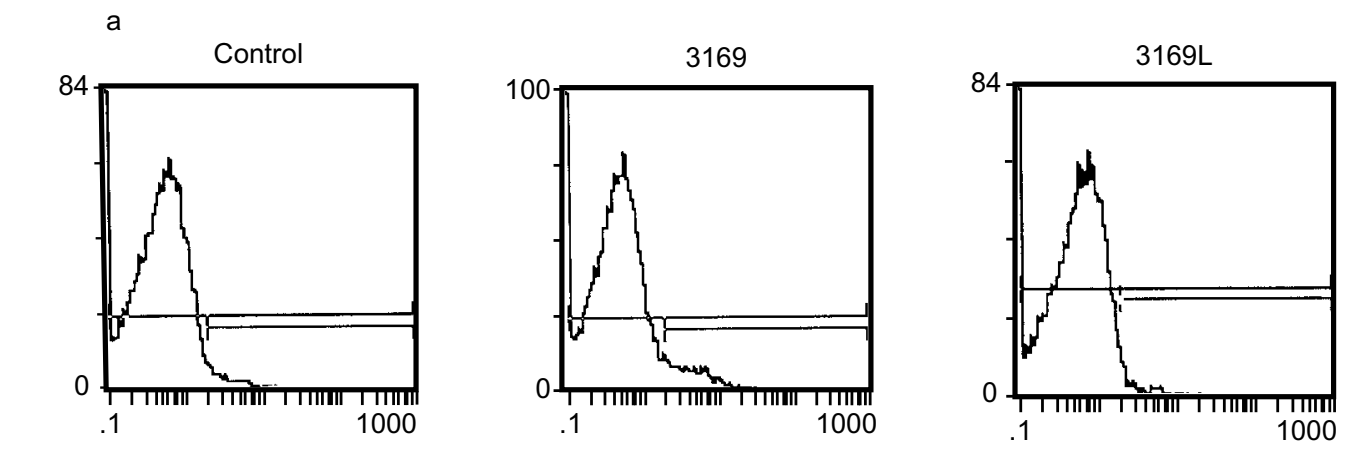

$\stackrel{+}{气}$

b

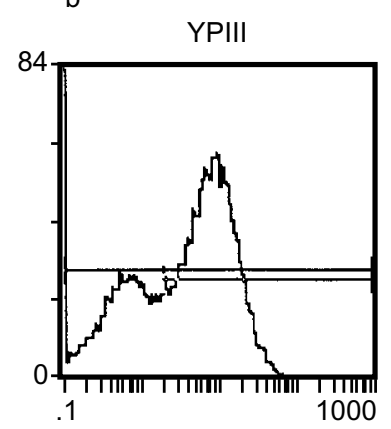

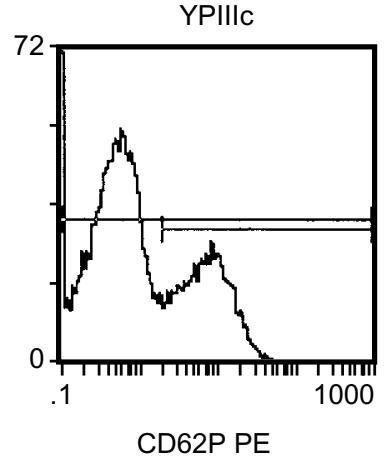

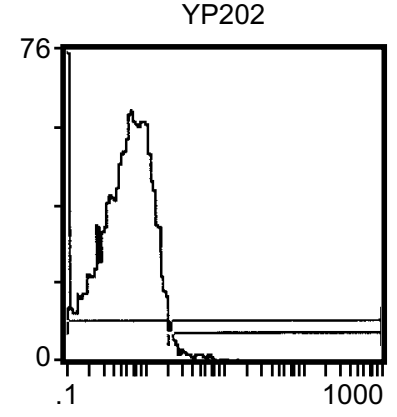

Fig. 4. Platelet activation by $Y$. enterocolitica and Y. pseudotuberculosis. Platelets were incubated with bacteria for $60 \mathrm{~min}$ at a bacteria to platelet ratio of 5:1. Activation was determined by dual staining of platelets with CD42b-PC5 and CD62P. (a) Y. enterocolitica strains grown and incubated at $37^{\circ} \mathrm{C}$, conditions which promote platelet association. No increased CD62P expression was observed in platelets interacting with Y. enterocolitica strains. (b) Y. pseudotuberculosis strains grown and incubated at $22^{\circ} \mathrm{C}$, conditions which promote platelet association and aggregation. High levels of CD62P expression were observed with platelets interacting with the invasin-positive strains YPIII and YPIIIc; no increase was observed in the invasin-negative strain YP202.
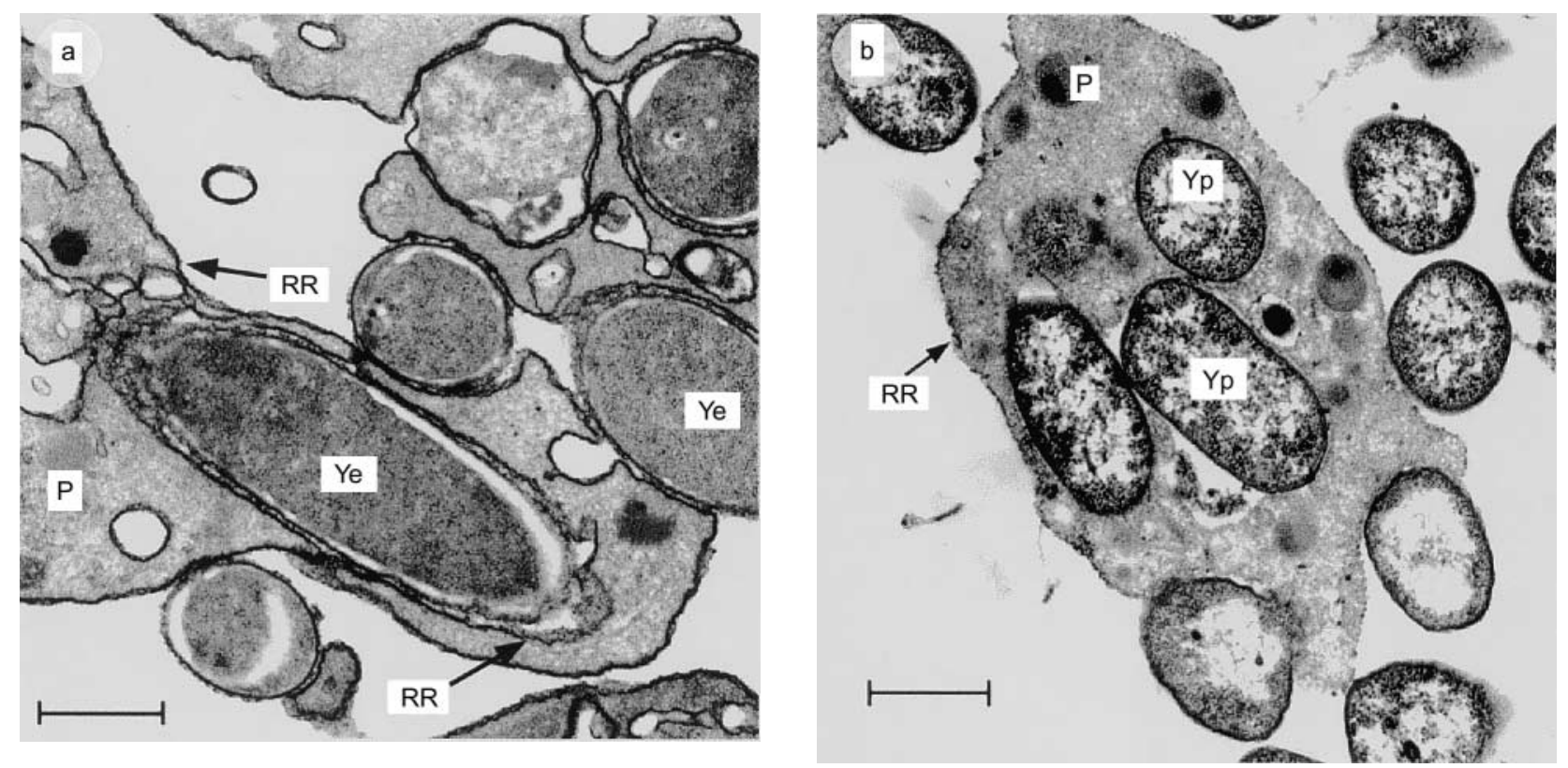

Fig. 5. Electron microscopy of platelets and Yersinia spp. (a) Y. enterocolitica 3169 grown at $37^{\circ} \mathrm{C}(\mathrm{Ye})$ or (b) Y. pseudotuberculosis YPIII grown $22^{\circ} \mathrm{C}(\mathrm{Yp})$ were incubated with platelets $(\mathrm{P})$ at growth temperature for $1 \mathrm{~h}$ then fixed and stained with ruthenium red as described in Materials and methods. Ruthenium red (RR) stains surface membranes and invaginations but does not stain vesicles cut off from the cell surface. Bar, $1 \mu \mathrm{m}$.

differently with platelets. Association of $Y$. enterocolitica 0:9 with platelets, as seen in flow cytometry, appeared to be greatly enhanced by the expression of virulence plasmid genes at $37^{\circ} \mathrm{C}$ but did not lead to platelet activation. Y. pseudotuberculosis had a more complex pattern of association with platelets in the flow cytometry system with a possible role for one or more thermo-inducible chromosomal factors (perhaps 


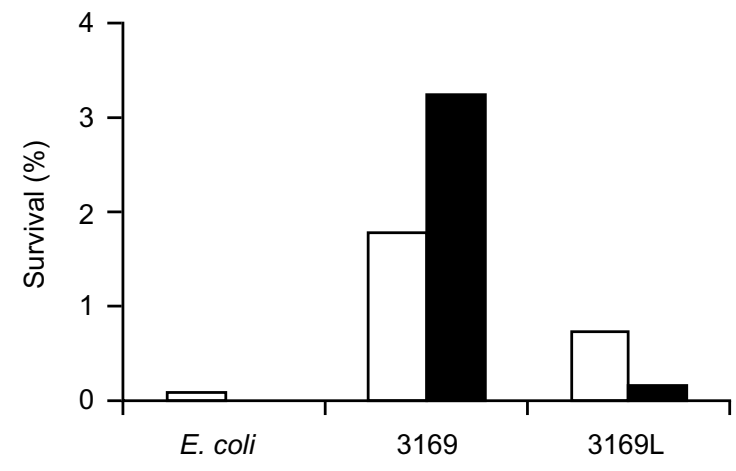

Fig. 6. Effect of platelets on bacterial survival in human serum. Bacterial strains containing green fluorescent protein (GFP) were incubated with $(\square)$ or without $(\square)$ platelets for $2 \mathrm{~h}$ in serum $30 \%$ at $37^{\circ} \mathrm{C}$. After incubation, Triton X-100 was added and the tests were analysed by flow cytometry. Survival was defined as the number of GFP events found after lysis with Triton X-100 divided by the number of GFP events in a control with no serum.

psa [34]) as well as inv and virulence plasmid genes. Activation of platelets, as seen in the aggregometer and by CD62P expression in flow cytometry, was seen only with $Y$. pseudotuberculosis and was seen only in the strains containing inv and grown at low temperature.

It has been demonstrated clearly by Simonet et al. [12] that activation of platelets by $Y$. pseudotuberculosis is due to interaction of invasin with $\beta 1$-integrin on the platelet membrane. As $Y$. enterocolitica also has an inv gene, which is very similar in its binding domains to that of Y. pseudotuberculosis [21], it is surprising that an equivalent effect was not seen with any of the $Y$. enterocolitica strains tested. However, recent work has shown that the invasin of $Y$. pseudotuberculosis can self-associate and that the region responsible for this is missing from the $Y$. enterocolitica inv gene [35]. Deletion of this self-associating region reduces uptake of $Y$. pseudotuberculosis into cultured cells, probably because self-association is required for clustering of the integrin receptor in the mammalian cells. This absence of the self-associating region in $Y$. enterocolitica and the consequent failure to cluster integrin receptors may explain the failure of $Y$. enterocolitica strains to activate platelets.

The association of $Y$. enterocolitica serotype O:9 with platelets is dependent on the presence of the virulence plasmid and growth at $37^{\circ} \mathrm{C}$. This indicates the involvement of a temperature-dependent plasmid-encoded protein. YadA, the best studied adhesin on the $Y$. enterocolitica virulence plasmid [6], seems the most likely candidate. However, $\mathrm{pYV}^{+} \mathrm{O}: 3$ strains and the well characterised $\mathrm{pYV}^{+} \mathrm{O}: 8$ strain 314 did not bind to platelets. YadA from serotypes O:3 [36] and O:9 (M. Iriarte, C. Kerbourch and G. R. Cornelis, GenBank accession no. AF056092) are only 97\% identical in amino acid sequence, whereas YadA of serotype O:8 has two deletions compared to O:3 or O:9 [36]. Thus, the difference in behaviour may be explained by differences on YadA. Alternatively, the adhesin may be another protein that is found on the virulence plasmid of $Y$. enterocolitica serotype $0: 9$ but not $\mathrm{O}: 8$ or O:3. The virulence plasmids are known to be conserved in size within serotypes but show differences in size and sequence homology between serotypes [37], so they may possess distinct adhesins.

These findings are also consistent with the observation that $\mathrm{pYV}^{+} Y$. pseudotuberculosis in mouse tissues is extracellular and associated with platelets [16]. There was an inconsistency between the latter observation and the subsequent in-vitro demonstration of aggregation and invasion of platelets by a mechanism that involved invasin [12] that can now be easily explained. The failure of the in-vitro study to detect a pYV-dependent mechanism of interaction between $Y$. pseudotuberculosis and platelets occurred because the aggregometer assay used was not able to detect interaction without activation.

The findings of the present study are significant for blood transfusion because they help define the possible mechanism by which $Y$. enterocolitica survives and multiplies in blood and they allow some optimistic predictions to be made about the effect of leukodepletion by filtration on $Y$. enterocolitica O:9. Previous experiments with $Y$. enterocolitica $0: 9$ came to the conclusion that there must be a protected site in blood where the bacterium can survive until sufficient cooling has occurred to stop complement activity [18]. The present findings support the possibility that platelets may provide that protected site. The degree of protection that the study was able to demonstrate was not dramatic, but it is not known how much protection is required to allow $Y$. enterocolitica to survive in some donations, nor is it known how the natural history may differ from these experiments. Further experiments are required to elucidate the relative roles of platelets and leucocytes. Future studies should also address the finding of differences in interaction with blood elements by different serotypes of $Y$. enterocolitica.

This study was supported by grant no. 9806 from the Bayer Blood Partnership. We are grateful to Leona Barclay for the electron micrographs.

\section{References}

1. Sazama K. Bacteria in blood for transfusion. A review. Arch Pathol Lab Med 1994; 118: 350-365.

2. Anon. Red blood cell transfusions contaminated with Yersinia enterocolitica - United States, 1991-1996, and initiation of a national study to detect bacteria-associated transfusion reactions. MMWR Morbid Mortal Wkly Rep 1997; 46: 553-555.

3. Theakston EP, Morris AJ, Streat SJ, Baker BW, Woodfield DG. Transfusion transmitted Yersinia enterocolitica infections in New Zealand. Aust NZ J Med 1997; 27: 62-67.

4. Anon. Bacterial contamination of blood and blood products. In: Binder S, Levitt AS (eds) Preventing emerging infectious diseases. Atlanta, GA, Center for Disease Control and Prevention. 1998: 10.

5. Bottone EJ. Yersinia enterocolitica: the charisma continues. 
Clin Microbiol Rev 1997; 10: 257-276.

6. Cornelis GR, Boland A, Boyd AP et al. The virulence plasmid of Yersinia, an antihost genome. Microbiol Mol Biol Rev 1998; 62: $1315-1352$

7. Ruckdeschel K, Roggenkamp A, Lafont V, Mangeat P, Heesemann J, Rouot B. Interaction of Yersinia enterocolitica with macrophages leads to macrophage cell death through apoptosis. Infect Immun 1997; 65: 4813-4821.

8. Pai CH, DeStephano L. Serum resistance associated with virulence in Yersinia enterocolitica. Infect Immun 1982; 35: $605-611$.

9. Martinez RJ. Plasmid-mediated and temperature-regulated surface properties of Yersinia enterocolitica. Infect Immun 1983; 41: $921-930$.

10. Bliska JB, Falkow S. Bacterial resistance to complement killing mediated by the Ail protein of Yersinia enterocolitica. Proc Natl Acad Sci USA 1992; 89: 3561-3565.

11. Pepe JC, Badger JL, Miller VL. Growth phase and low $\mathrm{pH}$ affect the thermal regulation of the Yersinia enterocolitica inv gene. Mol Microbiol 1994; 11: 123-135.

12. Simonet M, Triadou P, Frehel C, Morel-Kopp MC, Kaplan C, Berche P. Human platelet aggregation by Yersinia pseudotuberculosis is mediated by invasin. Infect Immun 1992; 60: 366-373.

13. Ruckdeschel K, Roggenkamp A, Schubert S, Heesemann J. Differential contribution of Yersinia enterocolitica virulence factors to evasion of microbicidal action of neutrophils. Infect Immun 1996; 64: 724-733.

14. Anon. Standards for blood banks and transfusion services, 15 th edn. Bethesda, MD, American Association of Blood Banks. 1993: 8.

15. Hanski C, Kutschka U, Schmoranzer HP et al. Immunohistochemical and electron microscopic study of interaction of Yersinia enterocolitica serotype $\mathrm{O} 8$ with intestinal mucosa during experimental enteritis. Infect Immun 1989; 57: 673-678.

16. Simonet M, Richard S, Berche P. Electron microscopic evidence for in vivo extracellular localization of Yersinia pseudotuberculosis harboring the pYV plasmid. Infect Immun 1990; 58: 841-845.

17. Lian C-J, Hwang WS, Pai CH. Plasmid-mediated resistance to phagocytosis in Yersinia enterocolitica. Infect Immun 1987; 55: 1176-1183.

18. Gibb AP, Martin KM, Davidson GA, Walker B, Murphy WG. Modeling the growth of Yersinia enterocolitica in donated blood. Transfusion 1994; 34: 304-310.

19. Högman CF, Gong J, Hambraeus A, Johansson CS, Eriksson L. The role of white cells in the transmission of Yersinia enterocolitica in blood components. Transfusion 1992; 32: 654-657.

20. Gong J, Hogman CF, Hambraeus A, Johansson CS, Eriksson L. Transfusion-transmitted Yersinia enterocolitica infection. Protection through buffy coat removal and failure of the bacteria to grow in platelet-rich or platelet-poor plasma. Vox Sang 1993; 65: $42-46$.

21. Young VB, Miller VL, Falkow S, Schoolnik GK. Sequence, localization and function of the invasin protein of Yersinia enterocolitica. Mol Microbiol 1990; 4: 1119-1128.

22. Cormack BP, Valdivia RH, Falkow S. FACS-optimized mutants of the green fluorescent protein (GFP). Gene 1996; 173: (spec. no.) $33-38$.

23. Roggenkamp A, Ruckdeschel K, Leitritz L, Schmitt R, Heesemann J. Deletion of amino acids 29 to 81 in adhesion protein YadA of Yersinia enterocolitica serotype 0:8 results in selective abrogation of adherence to neutrophils. Infect Immun 1996; 64: 2506-2514.

24. Kooi C, Sokol PA. Characterization of monoclonal antibodies to Yersinia enterocolitica iron-regulated proteins. Can J Microbiol 1995; 41: 562-571.

25. Tipple MA, Bland LA, Murphy JJ et al. Sepsis associated with transfusion of red cells contaminated with Yersinia enterocolitica. Transfusion 1990; 30: 207-213.

26. Yanisch-Perron C, Vieira J, Messing J. Improved M13 phage cloning vectors and host strains: nucleotide sequences of the M13mp18 and pUC19 vectors. Gene 1985; 33: 103-119.

27. West SE, Schweizer HP, Dall C, Sample AK, Runyen-Janecky LJ. Construction of improved Escherichia-Pseudomonas shuttle vectors derived from pUC18/19 and sequence of the region required for their replication in Pseudomonas aeruginosa. Gene 1994; 148: 81-86.

28. Birnboim HC, Doly J. A rapid alkaline extraction procedure for screening recombinant plasmid DNA. Nucleic Acids Res 1979; 7: 1513-1523.

29. Maniatis T, Fritsch EF, Sambrook J. Molecular cloning: a laboratory manual. Cold Spring Harbor, NY, Cold Spring Harbor Laboratory. 1982.

30. Riley G, Toma S. Detection of pathogenic Yersinia enterocolitica by using congo red-magnesium oxalate agar medium. J Clin Microbiol 1989; 27: 213-214.

31. Conchas RF, Carniel E. A highly efficient electroporation system for transformation of Yersinia. Gene 1990; 87: $133-137$.

32. Roper-Drewinko PR, Drewinko B, Corrigan G, Johnston D, McCredie KB, Freireich EJ. Standardization of platelet function tests. Am J Hematol 1981; 11: 183-203.

33. Carmody MW, Ault KA, Mitchell JG, Rote NS, Ng AK. Production of monoclonal antibodies specific for platelet activation antigens and their use in evaluating platelet function. Hybridoma 1990; 9: 631-641.

34. Yang Y, Merriam JJ, Mueller JP, Isberg RR. The psa locus is responsible for thermoinducible binding of Yersinia pseudotuberculosis to cultured cells. Infect Immun 1996; 64: 2483-2489.

35. Dersch P, Isberg RR. A region of the Yersinia pseudotuberculosis invasin protein enhances integrin-mediated uptake into mammalian cells and promotes self- association. EMBO J 1999; 18: 1199-1213.

36. Skurnik M, Wolf-Watz H. Analysis of the yopA gene encoding the Yop1 virulence determinants of Yersinia spp. Mol Microbiol 1989; 3: 517-529.

37. Heesemann J, Keller C, Morawa R, Schmidt N, Siemens HJ, Laufs R. Plasmids of human strains of Yersinia enterocolitica: molecular relatedness and possible importance for pathogenesis. J Infect Dis 1983; 147:107-115. 